\title{
Sedimentation Rates in the Western Philippine Sea
}

\author{
RON-SHENG ChEN \\ AND \\ YU-ChIA ChUng \\ Institute of Marine Geology \\ National Sun Yat-Sen University, Kaohsiung, Taiwan, R.O.C.
}

(Received 11 April 1990; revised 20 May 1990)

\begin{abstract}
Sedimentation rates in the western Philippine Sea have been determined on three piston cores using the excess ${ }^{230} T h$ method. In the deep basin, the sedimentation rates as determined from two cores are 5.3 and $6.8 \mathrm{~mm} \mathrm{ka}^{-1}$ at least for the past 70,000 years. Immediately before that time, a disturbed zone which is recognized at one station appears to have coincided with the onset of the last glaciation. Dating back further, the data suggest a higher sedimentation rate of 17.4 $m m \mathrm{ka}^{-1}$. However, the data are by no means unambiguous; another interpretation suggests a slower rate $\left(10.6 \mathrm{~mm} \mathrm{ka}^{-1}\right)$ between yet another disturbed zone at greater depth and the one just mentioned.

In the southwestern end of the Ryukyu Trench, the excess ${ }^{230} \mathrm{Th}$ activities are too low to allow a meaningful treatment with this method. The sedimentation rate is expected to be high due to the geologic environment of the trench. A value of about $13 \mathrm{~mm} \mathrm{ka}^{-1}$ with a large uncertainty is obtained when the method is attempted. These sedimentation rates are quite consistent with those obtained in the Philippine Sea by earlier workers.
\end{abstract}

\section{INTRODUCTION}

Uranium series disequilibrium dating methods have long been used to study marine deposits (e.g., Goldberg and Koide, 1962; Ku, 1976; Nozaki et al., 1987). One of the most useful nuclides for deep-sea sediments dating is ${ }^{230} \mathrm{Th}$ which has a half-life of 75,200 years. The effective age dating with this nuclide may thus reach about 300,000 years. This age range extends that of ${ }^{14} C$ and is especially useful for studying Quaternary paleoclimatic changes (Kennett, 1982). Due to its reactivity in seawater, ${ }^{230} T h$ is readily removed from the water column where it is produced by the decay of ${ }^{234} \mathrm{U}$. The removal of ${ }^{230} \mathrm{Th}$ by sinking particulates results in an enrichment of the surface sediments with this nuclide. 
This excess of unsupported ${ }^{230} \mathrm{Th}$ can be used as a "clock" to determine the time elapsed since the sediments buried beneath have been deposited (Goldberg and Koide, 1962; Ku, 1976; Anderson, 1981). This paper is to report the sedimentation rates in the western Philippine Sea as determined from three piston cores using the excess ${ }^{230} \mathrm{Th}$ method. Changes in the sedimentation rate are also discussed in relation to recent glaciations.

\section{METHOD OF ANALYSIS}

Three piston cores were taken from the western Philippine Sea during an expedition with R/V Ocean Researcher I in March, 1988. Station locations designated as St6, St7 and St8 are plotted in a bathymetric map shown in Fig. 1; water depth, core length and coordinate of these stations are given in Table 1. Station 6 is located in the trough east of the Gagua Ridge; station 7 is in a deep basin about $100 \mathrm{~km}$ to the south of the Ryukyu Trench; and station 8 is within the southwestern end of the trench.

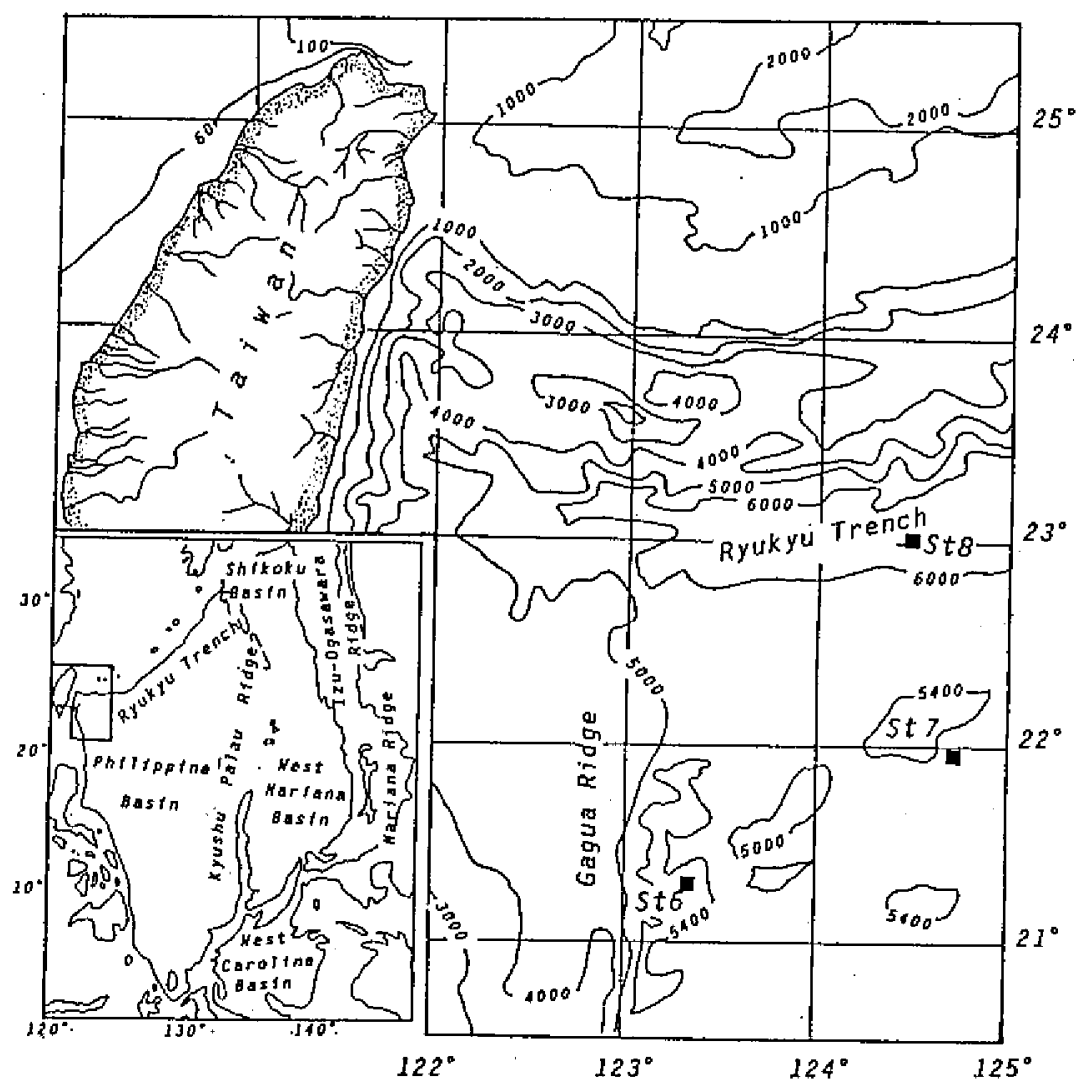

Fig. 1. Map showing locations where piston cores were taken. Contours in
athymetry are in meters. 
Sediment samples were collected from each core at desired depths for chemical and rediochemical analyses. Each sample was dried at $110^{\circ} \mathrm{C}$, homogenized, and then ashed at $550^{\circ} \mathrm{C}$ for 4 hours to remove the organic matter. The loss in weight due to ashing may serve as a crude estimate for the content of the organic matter (Tsai and Chung, 1989). About $0.1 \mathrm{~g}$ of each ashed sample was dissolved in a mixture of $\mathrm{HClO}_{4}, \mathrm{HNO}_{3}$ and $\mathrm{HF}$ (2:4:4) with a teflon digestion bomb. Concentrations of $M n, F e$, and $A l$ etc. were determined using an atomic absorption spectrophotometer. $\mathrm{CaCO}_{3}$ content was determined by acid reaction to release $\mathrm{CO}_{2}$. The contents of the organic matter, $\mathrm{Fe}, \mathrm{Mn}, \mathrm{Al}$ and $\mathrm{CaCO}_{3}$ in the sediments are listed in the Appendix.

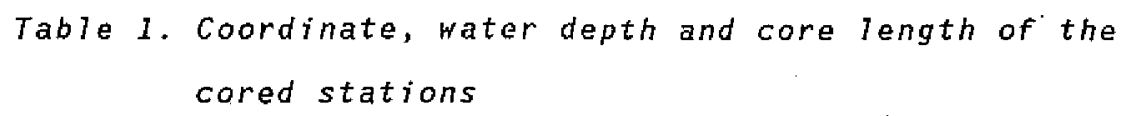

\begin{tabular}{lccc}
\hline \hline St \# & Coordinate & Water depth & core length \\
& & (m) & (cm) \\
\hline St 6 & $21^{\circ} 18.0^{\prime} \mathrm{N} ; 123^{\circ} 20.8^{\prime} \mathrm{E}$ & 5600 & 185 \\
St 7 & $21^{\circ} 56.3^{\prime} \mathrm{N} ; 124^{\circ} 41.3^{\prime} \mathrm{E}$ & 5700 & 508 \\
St 8 & $23^{\circ} 02.9^{\prime} \mathrm{N} ; 124^{\circ} 31.6^{\prime} \mathrm{E}$ & 6450 & 181 \\
\hline
\end{tabular}

Radiochemical analysis for $T h$ and $U$ isotopes was carried out on 2 to $3 g$ of each ashed sample. The chemical procedures were similar to that described by Anderson (1981) and Sheng (1984). Appropriate amounts of ${ }^{236} U$ and ${ }^{229} \mathrm{Th}$ tracers were added to each sample before it was treated with a mixture of $\mathrm{HCl}, \mathrm{HClO}_{4}$ and $\mathrm{HF}$ to achieve a total dissolution. $\mathrm{Th}$ and $U$ were then coprecipitated with concentrated $\mathrm{NH}_{4} \mathrm{OH}$. Further separation and purification of these two elements from the precipitate were performed according to standard ion exchange procedures. Finally, the $U$ and $T h$ were electroplated separately onto silver discs. The relative abundance of the isotopes was determined with a silicon surface barrier detector attached to a multi-channel analyzer.

\section{3. $F e, M n, A l$ AND ORGANIC MATTER DISTRIBUTIONS}

Source strength and preservation of organic matter are important factors in controlling the organic matter content in marine sediments (Lyle et al., 1989). In general, the organic matter content in a core may decrease with its depth due to bacterial decomposition (Middelburg, 1989). The depth distribution of the organic matter contents in the cores taken from stations 6,7 and 8 is shown in Fig. 2 . The organic matter content in the top $20 \mathrm{~cm}$ of the core 
is lower at station 8 than at other stations. At station 8 the organic matter content actually increases with depth to a maximum of $5 \%$ at $55 \mathrm{~cm}$. This suggests that the organic matter at this station is better preserved and so the distribution is controlled mainly by the supply of organic matter.
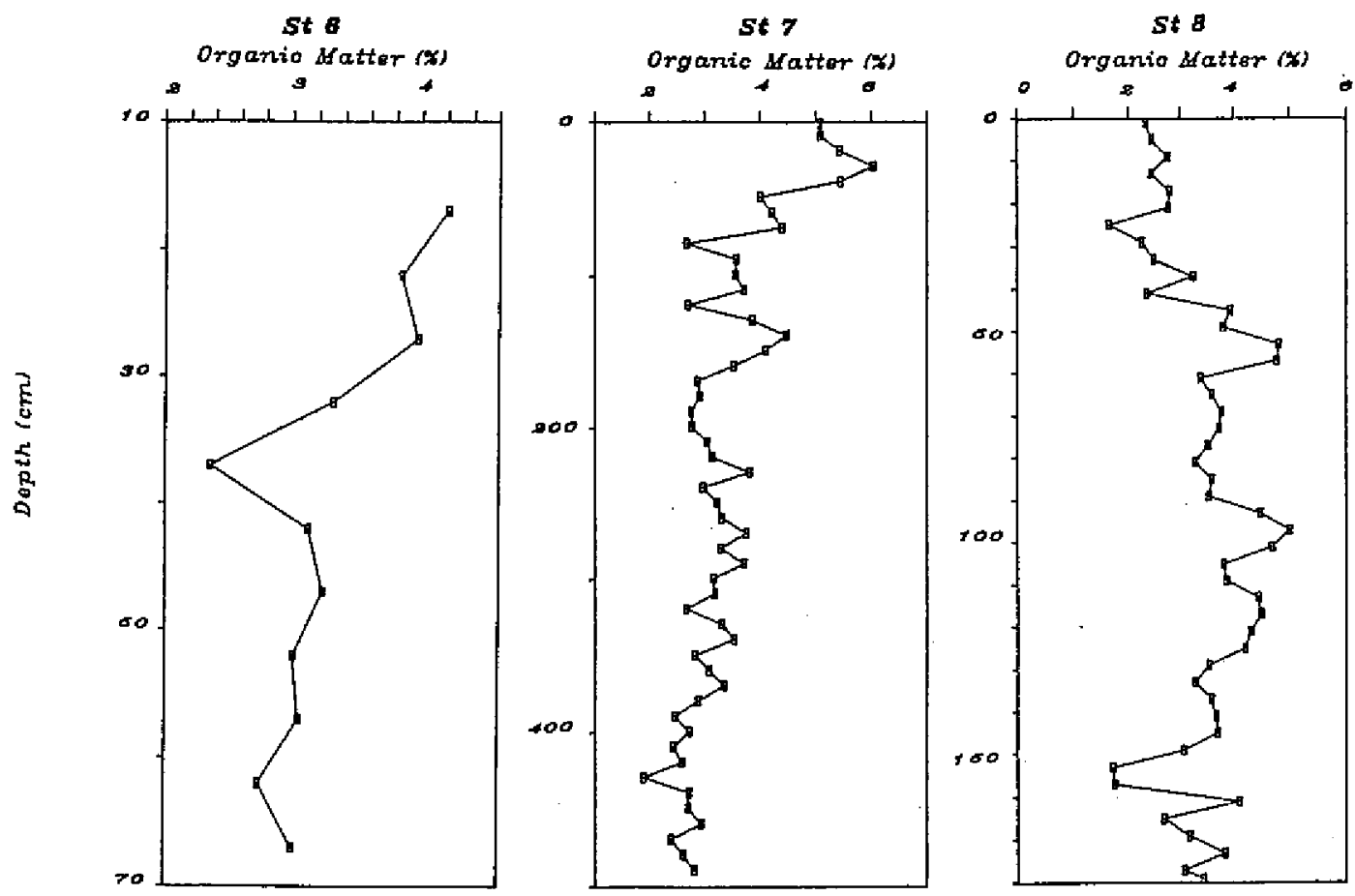

Fig. 2. Distribution of organic matter contents in the piston cores taken from stations 6,7 and 8 .

Trace metals may provide some clues to the source(s) of the sediments. Fig. 3 and Fig. 4 show respectively the $F e$ vs $A l$ and $M n$ vs $A l$ plots for these cores at all depths. The mean ratios of major igneous rock types and the mean crustal ratio (Krauskopf, 1979) are indicated for comparison. The data points plotted for $\mathrm{Fe}$ vs $\mathrm{Al}$ in these cores fall within the domain of the mean $\mathrm{Fe} / \mathrm{Al}$ ratios for the mafic rocks and felsic rocks and match the mean crustal ratio fairly well, suggesting a possible origin of intermediate igneous rocks.

As $M n$ is a minor or trace element in igneous rocks, the effects of dissolution, substitution and absorption upon $M n$ during erosion, transport and deposition may cause significant $M n$ variations in the sediments (Krauskopf, 1979). Since $M n$ variations in these cores are significantly larger than $F e$ variations, the $M n$ vs $A l$ plots as shown in Fig. 4 are quite scattered. $M n$ values greater than $0.26 \%$ are not included in the figure. One of these values even exceeds $1.1 \%$; 


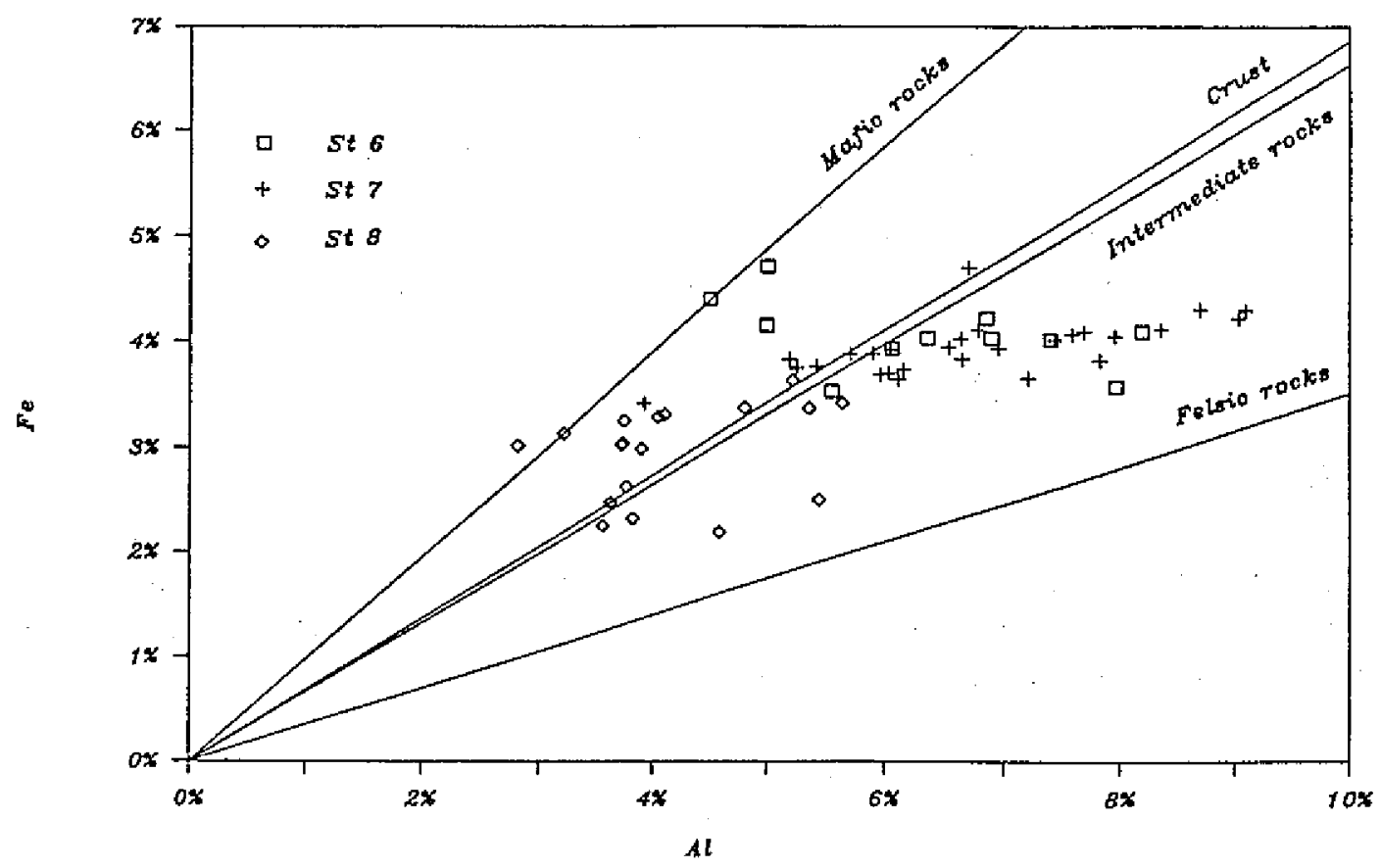

$F i g$. 3. $F e$ vs $A l$ plots for the piston cores from stations 6,7 and 8 . The ratios as indicated by straight lines for major igneous rocks and the crust are based on Krauskopf (1979).

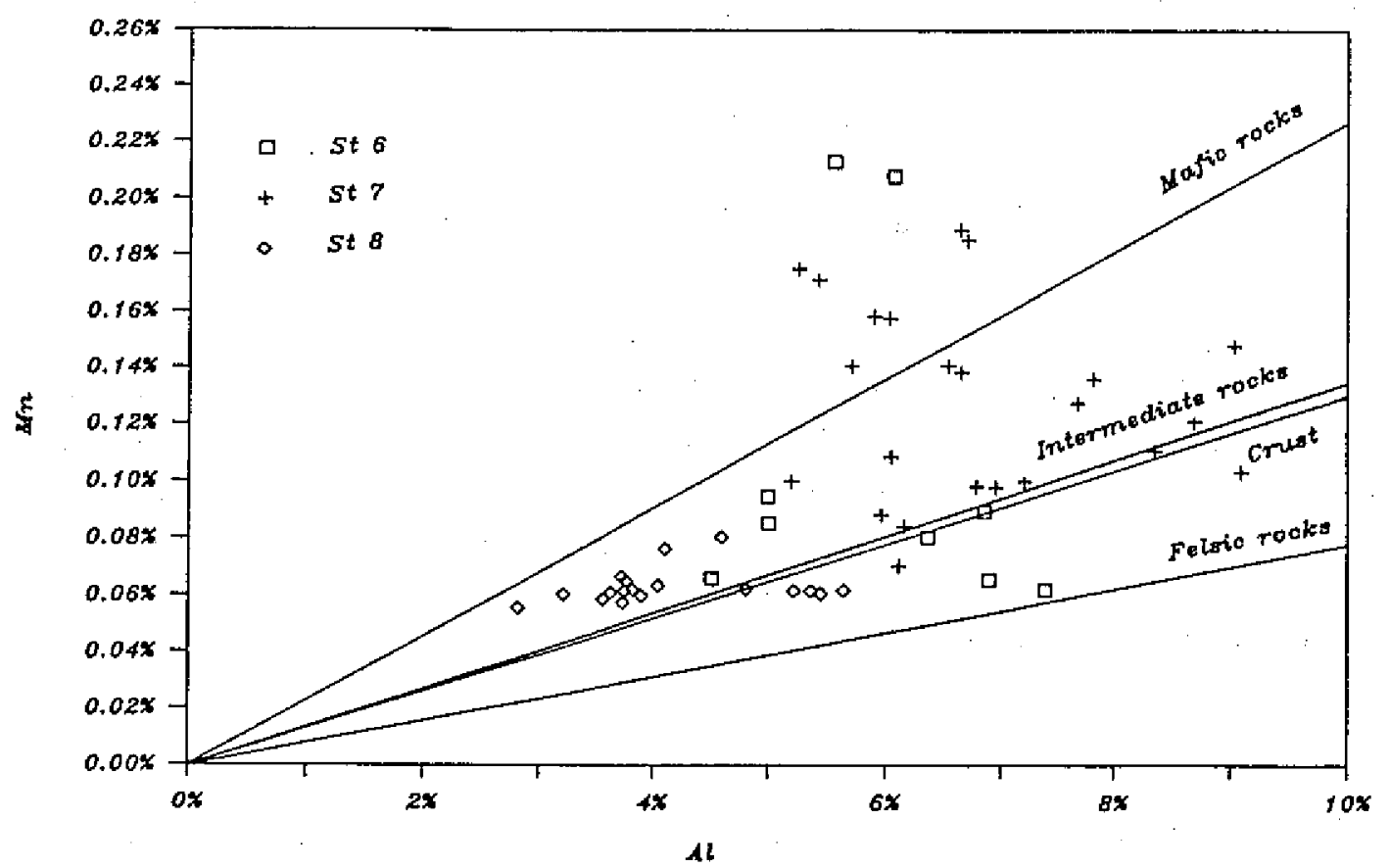

Fig. 4. $M n$ vs $A l$ plots for the piston cores from stations 6, 7 and 8 . The ratios for major igneous rocks and the crust as indicated are based on Krauskopf (1979). 
these high values are all from stations 6 and 7 . At station 8 all the plotted data points fall within the ratios for mafic and felsic rocks with a fairly constant $M n$ value at $0.06 \%$. The redox condition at station 8 is quite different from that at other stations. Due to a reductive environment, vey little $\mathrm{MnO}_{2}$ deposition was observed in the core at station 8. This argument is supported by the fact that organic matter is better preserved at this station than at the other stations.

\section{SEDIMENTATION RATES}

\section{a. Model}

A general one-dimensional steady-state model is often used to describe the vertical distribution of a radionuclide in a sediment column (Ku, 1976; Turekian and Cochran, 1976). The model equation can be written as

$$
D \frac{d^{2} C}{d z^{2}}-S \frac{d C}{d z}-\lambda C=0
$$

where $z$ is the core depth, $C$ is the excess (unsupported) activity of the nuclide in question, $D$ is the mixing coefficient for the sediments, $S$ is the sedimentation rate, and $\lambda$ is the decay constant of the nuclide. In the case where the mixing processes are small enough to be negligible, equation (1) may be simplified to

$$
S \frac{d C}{d z}+\lambda C=0
$$

If the boundary conditions are $C=C_{0}$ at $z=0 ; C \rightarrow 0$ as $z \rightarrow \infty$, then the solution is

$$
C=C_{0} e^{-(\lambda / s) z},
$$

where $C_{o}$ is the excess ${ }^{230} T h$ activity at the surface of the core and $\lambda$ is the decay constant for ${ }^{230} T h$ in our case. Equation (3) can be rewritten in a logarithmic form and the slope of the semi-log plots for the excess ${ }^{230} \mathrm{Th}$ activity vs depth provides a means to calculate the sedimentation rate. However, the plots may often deviate from linearity if the sedimentation rate is not uniform or if the sediment column has been disturbed.

\section{b. Results and discussion}

The results of the $U$ and $T h$ isotopic analyses for the cores are listed in Table 2. The errors quoted are mainly one-sigma counting statistics which are generally less than $10 \%$, with an average of about $5 \%$. Fig. 5 shows plots of the excess ${ }^{230} T h$ vs depth for. station 6 in a semi-log form. Based on the 
Table 2. U and Th isotopes for the cores taken from stations 6,7 and 8 .

\begin{tabular}{|c|c|c|c|c|c|}
\hline $\begin{array}{r}\text { depth } \\
(\mathrm{cm})\end{array}$ & ${ }^{232} \mathrm{Th}$ & $230 \mathrm{Th}$ & $\begin{array}{c}22 B_{T h} \\
d_{\rho m} / g\end{array}$ & $238_{u}$ & $234 v$ \\
\hline \multicolumn{6}{|l|}{$5 t 6$} \\
\hline $11-13$ & $2.56 \pm 0.17$ & $12.50 \pm 0.68$ & $2.88 \pm 0.18$ & $1.13 \pm 0.05$ & $1.10 \pm 0.05$ \\
\hline $16=18$ & $2.21 \pm 0.16$ & $11.01 \pm 0.49$ & $2.28 \pm 0.13$ & $0.99 \pm 0.05$ & $1.02 \pm 0.05$ \\
\hline $21-23$ & $2.30 \pm 0.13$ & $11.38 \pm 0.52$ & $2.61 \pm 0.15$ & $0.88 \pm 0.05$ & $1.02 \pm 0.04$ \\
\hline $26-28$ & $2.70 \pm 0.14$ & $8.39 \pm 0.37$ & $2.76 \pm 0.14$ & $0.98 \pm 0.04$ & $0.98 \pm 0.06$ \\
\hline $31-33$ & $2.52 \pm 0.13$ & $3.73 \pm 0.19$ & $3.78 \pm 0.17$ & $I .33 \pm 0.06$ & $1.25 \pm 0.05$ \\
\hline $36-3.8$ & $2.87 \pm 0.14$ & $1.74 \pm 0.09$ & $2.79 \pm 0.13$ & $1.38 \pm 0.07$ & $1.50 \pm 0.07$ \\
\hline $41-43$ & $2.77 \pm 0.18$ & $0.81 \pm 0.48$ & $2.76 \pm 0.18$ & $1.15 \pm 0.06$ & $1.10 \pm 0.05$ \\
\hline $46-48$ & $2.08 \pm 0.14$ & $7.78 \pm 0.43$ & $2.00 \pm 0.13$ & $0.96 \pm 0.05$ & $0.85 \pm 0.04$ \\
\hline $51-53$ & $2.09 \pm 0.12$ & 4.7940 .23 & $2.32 \pm 0.12$ & $1.24 \pm 0.07$ & $1.22 \pm 0.06$ \\
\hline $56-58$ & $3.04 \pm 0.17$ & $6.31 \pm 0.33$ & $2.80 \pm 0.16$ & $1.37 \pm 0.07$ & $1.35 \pm 0.07$ \\
\hline $61-63$ & $1.78 \pm 0.12$ & $4.51 \pm 0.26$ & $I .66 \pm 0.11$ & -- & $\cdots \quad m$ \\
\hline $66-68$ & $1.82 \pm 0 . i 1$ & $5.42 \pm 0.28$ & $1.76 \pm 0.10$ & $1.03 \pm 0.05$ & $0.94 \pm 0.05$ \\
\hline $86-88$ & $2.38 \pm 0.09$ & $4.60 \pm 0.16$ & $2.51 \pm 0.09$ & $1.01 \pm 0.05$ & $0.98 \pm 0.03$ \\
\hline $106-108$ & $2.00 \pm 0.09$ & $3.03 \pm 0.13$ & $1.85 \pm 0.09$ & $1.10 \pm 0.05$ & $1.07 \pm 0.05$ \\
\hline $126-128$ & $2.42 \pm 0.10$ & $2.20 \pm 0.09$ & $2.42 \pm 0.10$ & $1.16 \pm 0.04$ & $1.13 \pm 0.04$ \\
\hline $146-148$ & $2.05 \pm 0.11$ & $2.36 \pm 0.12$ & $2.28 \pm 0.12$ & $0.92 \pm 0.04^{\circ}$ & $1.05 \pm 0.04$ \\
\hline
\end{tabular}

St 7

$\begin{array}{cccc}0.2 & 3.04 \pm 0.16 & 12.81 \pm 0.55 & 3.06 \pm 0.16 \\ 4-6 & 3.02 \pm 0.20 & 12.18 \pm 0.66 & 2.88 \pm 0.19 \\ 8-10 & 3.41 \pm 0.23 & 11.32 \pm 0.64 & 3.29 \pm 0.22 \\ 12-14 & 3.06 \pm 0.15 & 9.91 \pm 0.13 & 2.93 \pm 0.15 \\ 18-20 & 3.21 \pm 0.23 & 9.48 \pm 0.56 & 3.22 \pm 0.23 \\ 28-30 & 2.60 \pm 0.19 & 8.74 \pm 0.52 & 3.30 \pm 0.23 \\ 38-40 & 3.10 \pm 0.18 & 7.92 \pm 0.39 & 3.46 \pm 0.19 \\ 48-50 & 3.11 \pm 0.20 & 7.35 \pm 0.43 & 3.02 \pm 0.20 \\ 68-70 & 2.05 \pm 0.16 & 7.84 \pm 0.49 & 1.89 \pm 0.15 \\ 78-80 & 2.13 \pm 0.15 & 4.55 \pm 0.29 & 2.38 \pm 0.16 \\ 98-100 & 3.28 \pm 0.19 & 6.96 \pm 0.34 & 3.22 \pm 0.17 \\ 108-110 & 2.82 \pm 0.16 & 6.94 \pm 0.35 & 2.93 \pm 0.16 \\ 118-120 & 3.27 \pm 0.22 & 7.54 \pm 0.46 & 3.12 \pm 0.21 \\ 138-140 & 3.38 \pm 0.21 & 9.45 \pm 0.47 & 3.37 \pm 0.19 \\ 158-160 & 3.29 \pm 0.25 & 3.02 \pm 0.55 & 3.03 \pm 0.23 \\ 178-180 & 3.11 \pm 0.14 & 7.13 \pm 0.30 & 3.05 \pm 0.14 \\ 198-200 & 2.84 \pm 0.14 & 6.07 \pm 0.30 & 3.07 \pm 0.14 \\ 218-220 & 2.72 \pm 0.16 & 5.75 \pm 0.31 & 2.94 \pm 0.15 \\ 238-240 & 3.01 \pm 0.19 & 4.70 \pm 0.35 & 3.05 \pm 0.19 \\ 258-260 & 2.78 \pm 0.19 & 5.74 \pm 0.35 & 2.79 \pm 0.19 \\ 278-280 & 3.22 \pm 0.21 & 4.49 \pm 0.28 & 3.20 \pm 0.21 \\ 298-300 & 3.37 \pm 0.22 & 4.48 \pm 0.28 & 2.94 \pm 0.21 \\ 318-320 & 3.51 \pm 0.18 & 4.37 \pm 0.22 & 3.08 \pm 0.16 \\ 358-360 & 3.16 \pm 0.19 & 3.52 \pm 0.21 & 2.88 \pm 0.18 \\ 398-400 & 2.92 \pm 0.16 & 3.90 \pm 0.20 & 3.01 \pm 0.15\end{array}$

$\begin{array}{ll}1.58 \pm 0.07 & 1.46 \pm 0.06 \\ 1.22 \pm 0.08 & 1.39 \pm 0.08 \\ 1.08 \pm 0.08 & 1.04 \pm 0.06 \\ 1.27 \pm 0.06 & 1.29 \pm 0.06 \\ 1.19 \pm 0.07 & 1.26 \pm 0.07 \\ 1.26 \pm 0.07 & 1.20 \pm 0.06 \\ 1.32 \pm 0.07 & 1.59 \pm 0.08 \\ 1.40 \pm 0.09 & 1.25 \pm 0.07 \\ 1.25 \pm 0.08 & 1.24 \pm 0.07 \\ 0.90 \pm 0.06 & 0.86 \pm 0.05 \\ 1.35 \pm 0.07 & 1.31 \pm 0.06 \\ 1.34 \pm 0.07 & 1.15 \pm 0.06 \\ 1.09 \pm 0.08 & 1.08 \pm 0.07 \\ 1.04 \pm 0.06 & 1.47 \pm 0.06 \\ 0.91 \pm 0.07 & 1.09 \pm 0.07 \\ 1.18 \pm 0.08 & 1.14 \pm 0.07 \\ 1.21 \pm 0.06 & 1.31 \pm 0.06 \\ 1.23 \pm 0.06 & 1.35 \pm 0.06 \\ 1.12 \pm 0.05 & 1.44 \pm 0.06 \\ 1.53 \pm 0.08 & 1.29 \pm 0.07 \\ 1.43 \pm 0.07 & 1.42 \pm 0.06 \\ 1.21 \pm 0.07 & 1.52 \pm 0.06 \\ 1.51 \pm 0.08 & 1.22 \pm 0.06 \\ 1.33 \pm 0.09 & 1.43 \pm 0.08 \\ 1.14 \pm 0.06 & 0.93 \pm 0.04\end{array}$




\begin{tabular}{|c|c|c|c|c|c|}
\hline $\begin{array}{r}\text { depth } \\
(\mathrm{cm})\end{array}$ & ${ }^{232} \mathrm{Th}$ & $230 \mathrm{Th}$ & $\begin{array}{c}228 T h \\
d p m / g)\end{array}$ & $238_{U}$ & $234 u$ \\
\hline $428-430$ & $2.57 \pm 0.21$ & $2.84 \pm 0.24$ & $2.47 \pm 0.21$ & $1.24 \pm 0.05$ & $1.10 \pm 0.04$ \\
\hline $448-450$ & $3.21 \pm 0.21$ & $2.09 \pm 0.15$ & $3.09 \pm 0.23$ & $1.13 \pm 0.05$ & $1.20 \pm 0.04$ \\
\hline $468-470$ & $2.55 \pm 0.15$ & $2.51 \pm 0.16$ & $2.58 \pm 0.16$ & $1.19 \pm 0.06$ & $0.97 \pm 0.05$ \\
\hline $488-490$ & $2.61 \pm 0.12$ & $2.00 \pm 0.10$ & $2.82 \pm 0.12$ & $1.14 \pm 0.05$ & $1.02 \pm 0.04$ \\
\hline \multicolumn{6}{|l|}{ St 8} \\
\hline $0-2$ & $2.39 \pm 0.13$ & $0.81 \pm 0.06$ & $2.31 \pm 0.13$ & $0.63 \pm 0.04$ & $0.60 \pm 0.04$ \\
\hline $18-20$ & $2.42 \pm 0.16$ & $0.95 \pm 0.08$ & $2.03 \pm 0.14$ & $0.58 \pm 0.03$ & $0.53 \pm 0.03$ \\
\hline $38-40$ & $2.46 \pm 0.17$ & $0.95 \pm 0.08$ & $2.45 \pm 0.17$ & $0.66 \pm 0.04$ & $0.63 \pm 0.04$ \\
\hline $50-60$ & $1.93 \pm 0.12$ & $0.77 \pm 0.06$ & $2.02 \pm 0.13$ & $0.8 I \pm 0.05$ & $0.75 \pm 0.05$ \\
\hline $78-80$ & $2.07 \pm 0.11$ & $0.86 \pm 0.05$ & $2.09 \pm 0.13$ & $0.61 \pm 0.03$ & $0.58 \pm 0.04$ \\
\hline $98-100$ & $1.90 \pm 0.12$ & $0.90 \pm 0.08$ & $1.97 \pm 0.12$ & $0.74 \pm 0.04$ & $0.73 \pm 0.05$ \\
\hline $1 \triangle B=120$ & $1.49 \pm 0.11$ & $0.68 \pm 0.06$ & $1.51 \pm 0.12$ & $0.63 \pm 0.06$ & $0.61 \pm 0.05$ \\
\hline $138=140$ & $1.84 \pm 0.10$ & $0.80 \pm 0.05$ & $1.89 \pm 0.10$ & $0.73 \pm 0.05$ & $0.75 \pm 0.05$ \\
\hline $158-160$ & $2.06 \pm 0.09$ & $0.81 \pm 0.05$ & $2.13 \pm 0.09$ & $0.70 \pm 0.04$ & $0.71 \pm 0.05$ \\
\hline $178-180$ & $1.51 \pm 0.11$ & $0.60 \pm 0.06$ & $1.49 \pm 0.11$ & $0.60 \pm 0.05$ & $0.66 \pm 0.06$ \\
\hline
\end{tabular}

-. : Lost

best fit of the slope for the data points $\left(R^{2}=0.93\right)$, the sedimentation rate is calculated to be $5.3 \mathrm{~mm} \mathrm{ka}^{-1}$. With this rate, the age for the bottom of the core is about 270,000 years.

The excess ${ }^{230} \mathrm{Th}$ activities in core depth $32 \mathrm{~cm}$ and $37 \mathrm{~cm}$ are significantly lower than those measured immediately above or below. These low values could have been derived from dilution of ${ }^{230} \mathrm{Th}$ by rapidly deposited material (Nozaki et al., 1987). The sediments at $32 \mathrm{~cm}$ depth were thus probably deposited about 60,000 years ago.

The excess ${ }^{230} T h$ vs depth plots for station 7 were shown in Fig. 6 in which two different slopes are separated by a horizontal line. Based on the slope obtained from the top $50 \mathrm{~cm}$, the sedimentation rate is $6.8 \mathrm{~mm} \mathrm{ka}^{-1}$. From 140 $\mathrm{cm}$ to the bottom, the best fit slope yields a rate of $17.4 \mathrm{~mm} \mathrm{ka}^{-1}$. The "flat" region between 50 and $140 \mathrm{~cm}$ where the excess ${ }^{230} \mathrm{Th}$ remains fairly constant is designated as a "disturbed" zone. With a sedimentation rate of $6.8 \mathrm{~mm} \mathrm{ka}^{-1}$, the disturbed zone was finished about 73,000 years ago. Thus, this disturbed zone appears to match that observed at station 6 in time or age. They might reflect the same event. As the disturbed zones were concluded at a time when the last glaciation took place about 75,000 years ago with a lowering of the sea level, turbidity currents and slumping might have been active then. These processes could have produced submarine redeposition in a rapid fashion, showing constant or low ${ }^{230} T h$ excesses. As an alternative interpretation for the station 7 data, Fig. 7 is presented with three slopes of best fits separated by two "flat" 


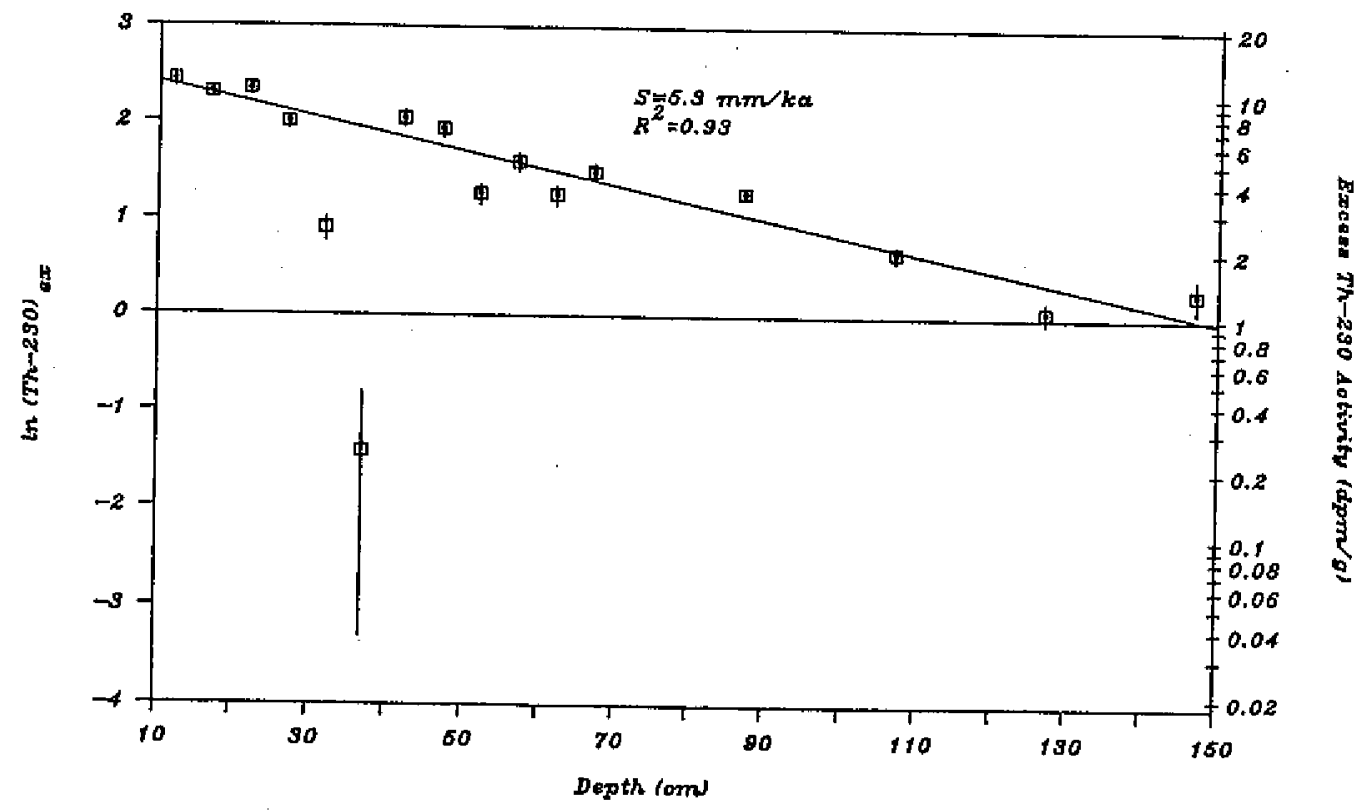

Fig. 5. Excess ${ }^{230} T h$ activities vs depth plots for the core from station 6 . Notice the logarithmic scale for excess ${ }^{230} T h$. The two low values (at 32 and 37 $\mathrm{cm}$ ) are excluded from the data fitting.

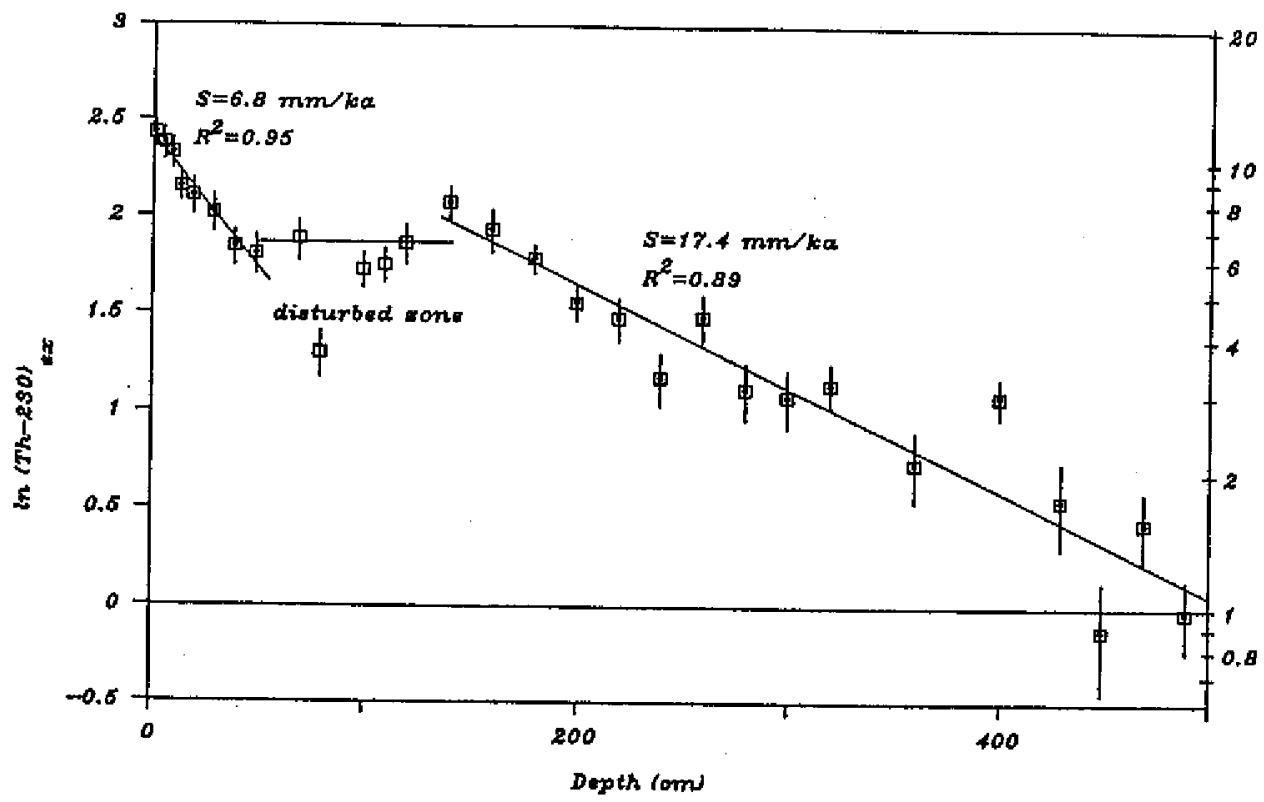

Fig. 6. Excess ${ }^{230} T h$ activities vs depth plots for the core from station 7 . Notice also the logarithmic scale for excess ${ }^{230} T h$. The "flat" portion between $50 \mathrm{~cm}$ and $140 \mathrm{~cm}$ depth is designated as a disturbed zone. 
regions of disturbed zones. The time span between the two disturbed zones is estimated to be about 94,000 years ( $100 \mathrm{~cm}$ length of core at a sedimentation rate of $10.6 \mathrm{~mm} \mathrm{ka}^{-1}$ ). This time scale appears to match glacial cycles for the Quaternary. Notice that the data points between the two disturbed zones show very good linearity with a correlation coefficient of 0.97 . The fitting for the region below the second disturbed zone is poor, showing a large uncertainty. Nevertheless, the sedimentation rate obtained $\left(8.4 \mathrm{~mm} \mathrm{ka}^{-1}\right)$ is not inconsistent with that of the other layers. This interpretation yields a closer rate within this core than the original interpretation which indicates a significantly higher rate beneath the first disturbed zone.

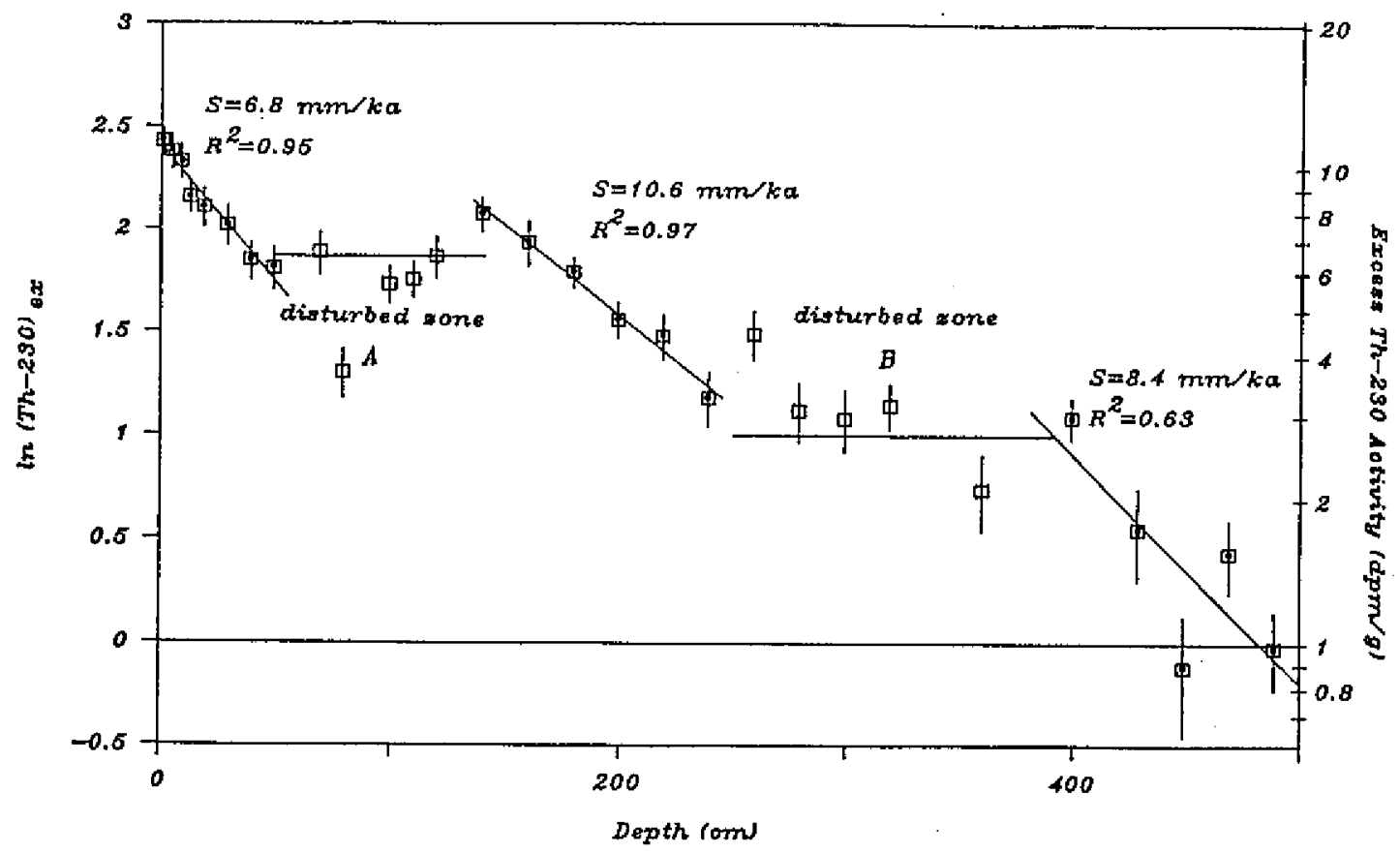

Fig. 7. Same plots as in Fig. 6 but an additional disturbed zone is recognized between $240 \mathrm{~cm}$ and $400 \mathrm{~cm}$ depth.

Excess ${ }^{230} T h$ activities at station 8 are too low to yield a reliable sedimentation rate from the model fitting. The best-fit slope corresponds to a rate of about $13 \mathrm{~mm} \mathrm{ka}^{-1}$, but with a poor correlation coefficient. The seismic data indicate that the Ryukyu Trench is an active subduction zone with a subduction rate of about $5 \mathrm{~cm} y^{-1}$ (Tsai et al., 1977). This geologic environment tends to favor a higher sedimentation rate, slumping from shallower depth for redeposition and so dilution of ${ }^{230} \mathrm{Th}$.

In addition to the excess ${ }^{230} \mathrm{Th}$ method, we have also used the excess ${ }^{230} T h /{ }^{232} T h$ method. The results agree quite well with that obtained with 
the excess ${ }^{230} \mathrm{~T} h$ method, suggesting that the ${ }^{230} \mathrm{Th}$ flux into the sediments has been fairly uniform for the past 270,000 years.

Plots of ${ }^{238} U$ vs ${ }^{232} T h$ in activity for all core samples (not shown here) indicate that ${ }^{232} \mathrm{Th}$ is enriched relative to ${ }^{238} \mathrm{U}$ in comparison with the average activity ratio for the deep-sea clay. ${ }^{238} U$ and ${ }^{234} U$ are essentially in radioactive equilibrium for the samples analyzed (Table 2).

\section{CONCLUSTON}

The sedimentation rates in the western Philippine Sea basin as obtained from stations 6 and 7 using the excess ${ }^{230} T h$ method are quite reliable and satisfactory with the exception that the lower portion of the core from station 7 may allow a different interpretation due to somewhat larger variations yet with an identifiable trend in the semi-log plots of excess ${ }^{230} \mathrm{~T} h$ vs core depth (Fig. 6 and Fig. 7). The sedimentation rates are $5.3 \mathrm{~mm} \mathrm{ka}^{-1}$ at station 6 for the past 270,000 years and $6.8 \mathrm{~mm} \mathrm{ka}^{-1}$ at station 7 for the past 74,000 years. Below the disturbed zone at station 7 , we obtain a sedimentation rate of $17.4 \mathrm{~mm} \mathrm{ka}^{-1}$ in a time span of about 200,000 years (Fig. 6). An alternative interpretation calls for a second disturbed zone located between 240 and 400 $\mathrm{cm}$ in core depth and comes up with a rate of $10.6 \mathrm{~mm} \mathrm{ka}^{-1}$ between the two disturbed zones (Fig. 7). More work is needed in order to resolve this problem.

In the southwestern end of the Ryukyu Trench where station 8 is located, the excess ${ }^{230} \mathrm{~T} h$ method is not suitable because of the extremely low excess ${ }^{230} \mathrm{Th}$ values (Table 2) and complicated environment. Nevertheless, the method has been attempted and a sedimentation rate of $13.2 \mathrm{~mm} \mathrm{ka}^{-1}$ has been obtained which is about twice that observed in the deep Philippine Sea basin. These results agree well with those reported by earlier workers (Sheng, 1984; Wang et al., 1987).

Acknowledgements. The authors have benefited from discussions with their colleagues during the course of this study. Financial supports have been provided by the National Science Council (NSC 78-0209-M110-03) and partially by the Atomic Energy Commission $\left({ }^{229} T h\right.$ and ${ }^{236} U$, the spikes used for $T h$ and $U$ isotopic analyses, have been provided by Professor T. L. Ku of the University of Southern California.). This paper is a condensed form of the senior author's (RSC) M. S. thesis completed at the Institute of Marine Geology, National Sun Yat-Sen University, Kaohsiung, Taiwan. He wishes to acknowledge his committee members for valuable discussions and suggestions. 


\section{APPENDIX}

Appendix : $\mathrm{Fe}, \mathrm{Hn}, \mathrm{Al}, \mathrm{CaCO}_{3}$ and Organic matter measured for the cores taken from stations 6,7 and 8 .

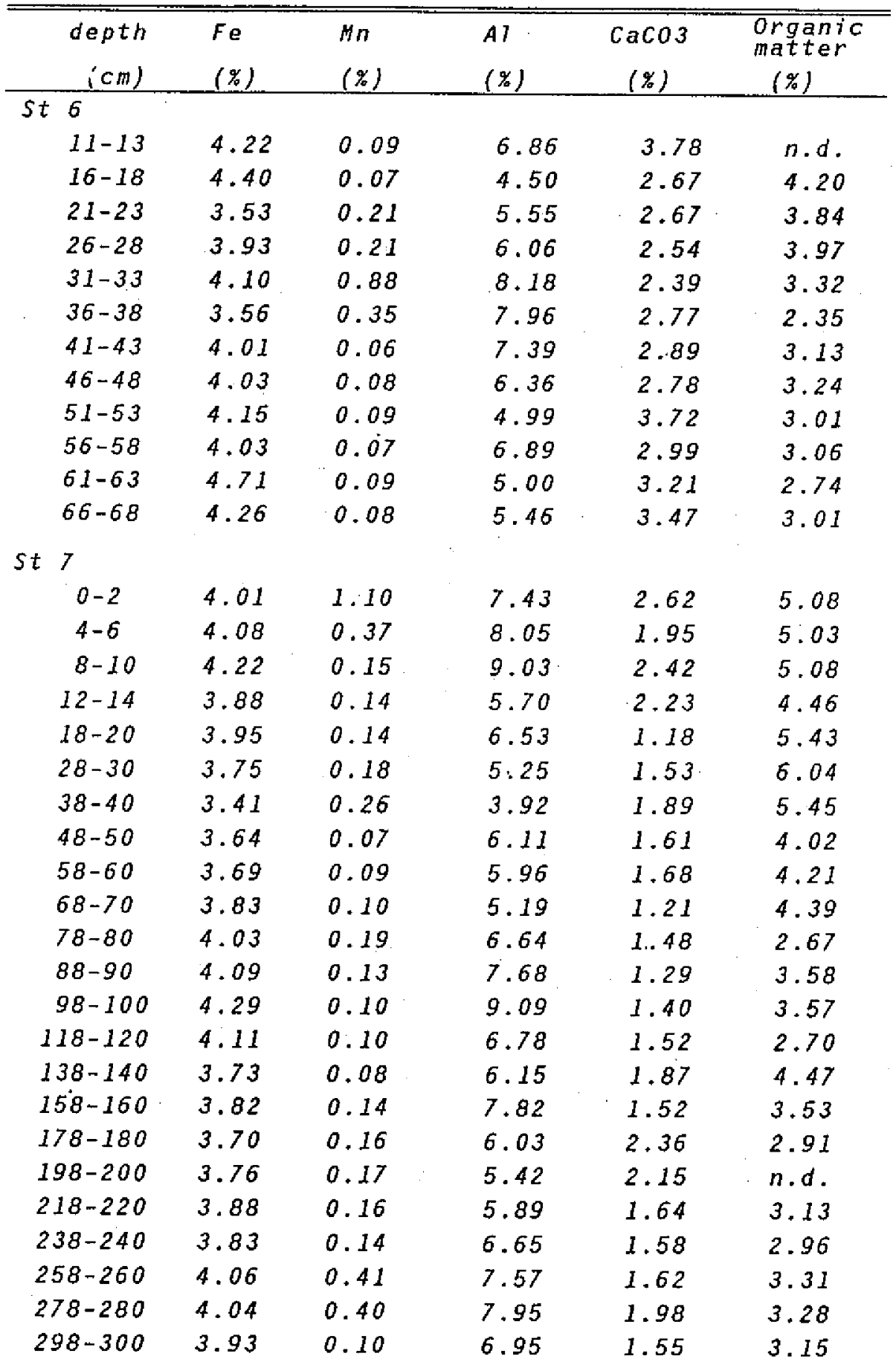




\begin{tabular}{cccccc}
\hline $\begin{array}{c}\text { depth } \\
(\mathrm{Cm})\end{array}$ & $\begin{array}{l}\text { Fe } \\
(\%)\end{array}$ & $\begin{array}{c}\text { Mn } \\
(\%)\end{array}$ & $\begin{array}{c}\text { CaCO3 } \\
(\%)\end{array}$ & $\begin{array}{c}\text { Organic } \\
\text { matter } \\
(\%)\end{array}$ \\
\hline $318-320$ & 4.70 & 0.19 & 6.70 & 2.52 & 2.65 \\
$338-340$ & 3.92 & 0.11 & 6.04 & 1.20 & 3.53 \\
$358-360$ & 4.12 & 0.11 & 8.35 & 2.24 & 3.07 \\
$378-380$ & 3.64 & 0.10 & 7.21 & 2.54 & 2.88 \\
$398-400$ & 4.30 & 0.12 & 8.69 & 1.85 & 2.71 \\
$438-440$ & 3.47 & 0.21 & 6.49 & 2.23 & 2.71 \\
$478-480$ & 3.60 & 0.52 & 4.44 & 1.63 & 2.60
\end{tabular}

St 8

\begin{tabular}{cccccc}
$0-2$ & 2.51 & 0.06 & 5.44 & 10.02 & 2.34 \\
$8-10$ & 2.19 & 0.08 & 4.58 & 11.11 & 2.76 \\
$18-20$ & 2.63 & 0.07 & 3.77 & 9.65 & 2.82 \\
$28-30$ & 2.32 & 0.06 & 3.82 & 8.01 & 2.26 \\
$38-40$ & 2.25 & 0.06 & 3.56 & 9.19 & 2.34 \\
$48-50$ & 3.03 & 0.07 & 3.72 & 8.80 & 3.80 \\
$58-60$ & 3.28 & 0.06 & 4.05 & 7.52 & 4.88 \\
$68-70$ & 3.42 & 0.06 & 5.64 & 6.91 & 3.76 \\
$78-80$ & -- & -- &.- & 4.75 & 3.92 \\
$88-90$ & 2.48 & 0.06 & 3.63 & 8.79 & 3.52 \\
$98-100$ & 3.03 & 0.06 & 3.73 & 6.26 & 4.67 \\
$108-110$ & 3.13 & 0.06 & 3.21 & 6.48 & 3.85 \\
$18-120$ & 3.37 & 0.06 & 5.36 & 6.78 & 4.10 \\
$188-130$ & 3.63 & 0.06 & 5.21 & 6.75 & 3.52 \\
$38-140$ & 2.98 & 0.06 & 3.90 & 6.21 & 3.57 \\
$48-150$ & 3.25 & 0.06 & 3.75 & 6.99 & 3.04 \\
$158-160$ & 3.02 & 0.06 & 2.82 & 6.68 & 3.92 \\
$168-170$ & 3.31 & 0.08 & 4.10 & 6.64 & 3.14 \\
$178-180$ & 3.37 & 0.06 & 4.80 & 7.04 & 4.41 \\
\hline
\end{tabular}

n.d.: not determined

- : lost

\section{REFERENCES}

Anderson. R. F., 1981: The marine geochemistry of thorium and protactium. Ph. D. Thesis, Massachusetts Institute of Technology. Woods Hole Oceanographic Institution, 287pp.

Goldberg, E. D. and M. Koide, 1962: Geochimcal studies of deep sea sediments by ionium/thorium method. Geochim. Cosmochim. Acta, 26, 417-450. 
Kennett, J., 1982: Marine geology, Prentice-Hall, Inc., Englewood Cliffs, N. J., $813 p p$.

Krauskopf K. B., 1979: Introduction to geochemistry, 2nd Ed. McGraw-Hill Book Co., New York. 721pp.

$\mathrm{Ku}, \mathrm{T} . \mathrm{L} ., 1976$ : The uranium-series method of age determination. Ann. Rev. Earth Planet. Sci. Lett., 4, 347-379.

Lyle, M., D. W. Murray, B. P. Finney, J. Dymond, J. M. Robbins and K. Brooksforce, 1988: The record of late pleistocene biogenic sedimentation in the eastern tropical Pacific ocean. Paleoceanography, 3, 39-59.

Middelburg, J. J., 1989: A simple rate model for organic matter decomposition in marine sediments. Geochim. Cosmochim. Acta, 53, 1577-1581.

Nozaki Y., M. Sato and K. Shimooka, 1987: Th-230 dating of $\sim 30 \mathrm{~m}$ long piston cores taken from two Atlantic abyssal plains during the ESOPE Cruise. Geochem. J., 21, 125-131.

Sheng, S. J., 1984: Analysis of thorium and uranium isotopes in deep sea sediments, Master thesis, National Tsing Hua University, 50pp (in Chinese).

Tsai, S. W. and Y. Chung, 1989: Pb-210 in the sediments of Taiwan Strait. Acta Oceanogr. Taiwanica, 22, 1-13.

Tsai, Y. B., T. L. Teng, J. M. Chiu and H. L. Liu, 1977: Tectonic implication of the seismicity in the Taiwan region. Memo. Geol. Soc. China, 2, 13-41.

Turekian, K. K. and J. K. Cochran, 1978: Determination of marine chronologies using natural radionuclides. Chemical Oceanography, 2nd Ed. 7, 313-360. Edited by Riley, J.P. and R. Chester, Pergamon Press.

Wang, C. -H., E. -F. Yu, S. -C. Shen, Z. -Y. Huang and J. -C. Chen, 1987: Rates of sedimentation in the Philippine Sea. Proc. Natl. Sci. Counc., ROC (A) 11, 197-202. 


\title{
西菲律賓海之沉積速率
}

\author{
陳榮盛 鍾玉嘉 \\ 國立中山大學海洋地質研究所
}

\section{摘 要}

西菲律賓海之沉皘速率由三活 塞岩心, 以超量針二三○定年法測定之, 在深海盈地區, 由兩岩心所得之沉積速率, 在過去七萬年間, 分別鹞每千年 5.3 與 6.8 毫米。在此之前有一

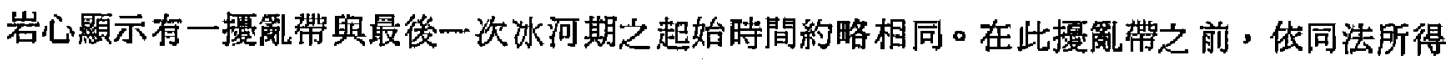
之沉積速率爲每千年 17.4 毫米, 但並非毫無問題。另一解釋則認临更早期亦有類似之摱亂 帶, 而界於此二摄亂帶間之沉積速率鸴每千年 10.6 撉米。

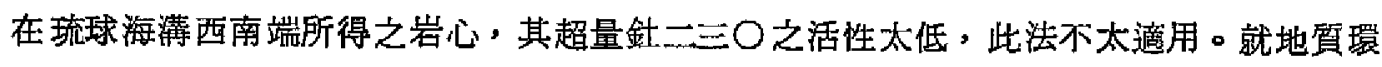

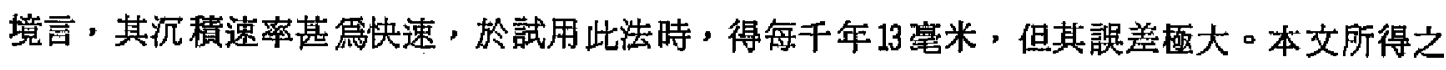
沉積速摔與前人在菲律賓海所得者大致相符。 